\title{
Optimal water intake for the elderly: prevention of hypotremia
}

\author{
P. Siregar ${ }^{1}$, E. Susalit ${ }^{1}$, R. Wirawan ${ }^{2}$, S. Setiati ${ }^{1}$, Sarwono W. ${ }^{1}$ \\ ${ }^{1}$ Department of Internal Medicine, Medical Faculty, University of Indonesia \\ ${ }^{2}$ Department of Clinical Pathology, Medical Faculty, University of Indonesia
}

\begin{abstract}
Abstrak
Tujuan Kekerapan hiponatremia pada usia lanjut cukup tinggi disebabkan adanya peningkatan kadar ADH, dan ANP yang merupakan bagian dari 8 perubahan fisiologi. Komplikasi yang ditimbulkan cukup spesifik yaitu meningkatnya risiko patah tulang, penurunan kesadaran hingga kejang-kejang. Penyebab tersering hiponatremia pada usia lanjut adalah asupan air yang tinggi. Mendapatkan asupan air optimal yaitu volume asupan air tertinggi yang tidak menimbulkan hiponatremia dan hipovolemia.
\end{abstract}

Metode Dilakukan penelitian pada 31 orang usia lanjut sehat setelah melalui pemilihan dari 107 usia lanjut secara simple random sampling dan kriteria eksklusi. Kemudian dibagi secara Randomisasi Blok dalam 5 kelompok asupan air $(1000-2500 \mathrm{~mL})$.

Hasil Dapat dibuktikan bahwa 1000 mL merupakan asupan air optimal pada usia lanjut sehat. Diperlihatkan juga bahwa kadar ADH plasma memiliki gambaran hubungan dengan volume asupan air yang tidak menimbulkan hiponatremia dan kadar NT-proBNP tidak berkorelasi dengan kadar natrium urin sewaktu. (Med J Indones 2009; 18: 18-25)

Kesimpulan Asupan air optimal pada usia lanjut adalah 1000 mL/24 jam.

\begin{abstract}
Aim The prevalence of hyponatremia in the elderly is quite high due to the rising of ADH and ANP concentrations which are part of eight physiologic changes. The complications are quite specific, among others, increased risk of bone fracture, declining of conciousness, and convulsion. The frequent cause of hyponatremia is high water intake. To achieve the optimal water intake designated as the highest water intake that did not cause hyponatremia and hypovolemia.

Methods A study was conducted on 31 healthy elderly subjects, selected from 107 persons using simple random sampling and exclusion criteria. By block randomisation were classified into five water-intake groups (1000-2500 $\mathrm{mL})$.

Results In this study, it could be proved that $1000 \mathrm{~mL}$ was the optimal. It was also unraveled that the ADH levels had a role in determining the water intake volume that did not cause hyponatremia and NT-proBNP concentrations did not correlate with spot urine sodium.
\end{abstract}

Conclusion The optimal water intake for the elderly is $1000 \mathrm{~mL}$ per day (Med J Indones 2009; 18: 18-25)

Keywords: Hyponatremia, healthy elderly, water intake

Water and electrolyte imbalances are frequently encountered in elderly people. This conditionis attributed to various changes that occur at the late age such as declined total body water volume, reduced glomerular filtration rate, reduced ability to produce hyperosmotic urine, increased $\mathrm{ADH}$ (anti diuretic hormone) and ANP (atrial natriuretic peptide) concentration, declined aldosteron concentration, reduced sensitiveness of the thirst central in central nervous system, and reduced free water clearance. ${ }^{1}$ Those changes lead to water retention and increased natrium excretion in urine that will easily cause hyponatremia. If not properly corrected, this condition will induce cerebral edema which, if it persists, will cause permanent damage to the brain. The cerebral tissue damage will be accelerated, if hyponatremia is accompanied by hypoxia. ${ }^{2,3}$ Chronic mild hyponatremia, in fact, could increase the risk of bone fractures in the elderly. ${ }^{4}$ Hypo natremia problems $(\mathrm{Na}<135 \mathrm{meq} / \mathrm{L})$ in the elderly have gained concern due to the increasing frequency. The frequency of hyponatremia at institutional elderly homes ranges from $4.2-18 \% .^{5-7}$ This frequency would get higher if 
monitored periodically for one year, ${ }^{5,6}$ namely between $31.3-53 \%$. The frequency of hyponatremic elderly patients hospitalized is even higher between 25 and $45 \%,{ }^{8,9}$ whereas the frequency of hyponatremic elderly patients taken care at home is lower, namely $8 \%{ }^{6}$

Excessive water intake is the frequent trigger for hyponatremia namely $78 \%$, in the institutional elderly homes. ${ }^{6}$ This condition is secondary to increased ADH in the elderly. The increase is caused by the hyperplasia of the paraventricular nucleus at the hypothalamus causing increased ADH secretion by the hypotalamus which as independent of the serum osmolality. ${ }^{10-12}$

In the elderly, the ANP concentration is increased. N-terminal of BNP (NT-proBNP) which is a homolog of ANP also increases in the elderly. The increase in NT-proBNP in the elderly will inhibit the reabsoption of sodium in the medullary colecting ducts of the kidney and will repress the production of angiotensin II as well as aldosteron so that natriuresis were increased. ${ }^{1}$ The increased natriuresis will certainly predispose hyponatremia to someone.

Case reports on severe hyponatremia caused by excessive water intake in the elderly people with high plasma ADH levels have been reported in Japan and Hungary. ${ }^{13,14}$ Other researchers, namely Chute JP at al. ${ }^{15}$ has done a metabolic study on 24 patients. Water and sodium restriction in patients with hyponatremia with increased ADH without increased ANP levels shows increased serum sodium concentration, but it does not occur in hyponatremia with increased ANP without increased $\mathrm{ADH}$ concentrations. Administration of water which is not excessive is one solution to prevent hyponatremia in the elderly.

Up to now there has been no study on how much water intake volume that is considered optimal for the elderly without causing either hypovolemia or hyponatremia. The survey done by Lindeman et al.revealed that water intake as many as 3-5 glasses of water per 24 hours could increase the BUN ratio (blood urea nitrogen) to creatinine or hypo $\neg$ volemia. Based on this survey, water intake up to 5 glasses of water per 24 hours was appropriate without causing hyponatremia. ${ }^{16,17}$

Optimal water intake volume for the elderly without causing hyponatremia would be determined in this study. The findings generated would serve as the guidance for the laymen or doctors dealing with the elderly at primary health care centers.

\section{METHODS}

\section{Selection of subjects and laboratory tests}

An experimental, analytic study was conducted on elderly population with the pre- and post-treatment designs. The study was carried out in one institutional elderly home that was accessible in Jakarta. The recruitment of subjects was conducted by simple ramdom sampling using random number table. The selected patients would be reselected based on the inclusion and exclusion criteria. The patients were then assigned to five groups by block randomization using random number table namely group I, water intake based on the standard ${ }^{16}$ group-II, water intake of $1000 \mathrm{~mL} / 24$ hour; group-III, $1500 \mathrm{~mL} / 24$ hours; group IV, $2000 \mathrm{~mL} / 24$ hours and group V, $2500 \mathrm{~mL} / 24$ hours. Intervention was carried out for two weeks to assess the decline in serum sodium concentrations. The minimal mean considered significant ${ }^{18}$ was $5 \mathrm{meq} / \mathrm{L}$ for determining of sample size. The age of subjects in the study was above 60 years, they were normovolemic and serum creatinine was less than $2 \mathrm{mg} / \mathrm{dL}$. They were excluded if they had diabetes melitus, abnormal cortisol levels (morning cortisol value 5-25 ug/dL), Hypothyroidism (FT4 $<0.89 \mathrm{ng} / \mathrm{dL}$ and TSH $>5.50 \mathrm{uIU}$ ), taking manitol, taking diuretics, had chronic diarrhea, heart failure, acute coronary syndrome $<60$ days, suspected of the risk of lung edema during water intake intervention, impression of wide anterior ischemia on ECG, nephrotic syndrome, liver cirrhosis, on steroids, and debilitating conditions that would complicate feeding and non-cooperative. The selected subjects underwent the tests of BUN, creatinine, morning urine sodium, serum sodium, potassium, and chloride concentrations, serum osmolality, morning urine osmolality, plasma $\mathrm{ADH}$, plasma NT-proBNP, serum cortisol levels, Free-T4, TSHs, fasting glucose level, CHE, Albumin/Globulin, urinalysis, ECG, body weight and height measurement. Blood sample taking for the laboratory tests was conducted at $7 \mathrm{am}$, following ten hours' fasting.

The water intake was defined as total water intake added by the water content derived from the food consumed. Daily recording of water intake volume per 24 hours by each individual in each group was carried out, from day 1 to day 14. At day 7 and 14, sodium, potassium, chloride, creatinine and BUN level in the serum were assessed. The intervention would be discon $\neg$ tinued if symptomatic hyponatremia manifested. 
During the intervention that lasted for 14 days, each subject was monitored for 24 hours every day from day one to day fourteen by one caregiver. Water intake forms were made uniform for all the caregivers. During the study, supervision of the caregivers was exercised to ensure recording of water intake and keeping an eye on the subjects continuously. To measure the water intake, measured glasses of the same type and shape were used by each of the subjects. Every day during the study, the food intake and the compositions namely sodium, carbohydrate and fat were supervised by one dietitian and one supervisor-senior dietitian. The compositions and the quantity of nutrients were attempted to be in the similar range during the study.

Statistical analysis was conducted on the discrepancy between the two means paired with the t-test or Wilcoxon test, between the unpaired means with the unpaired t-test or ANOVA or Kruskal-Wallis to compare the mean numeric variables between the two group categories in the more than two paired groups, repeated ANOVA or Friedman test to compare the mean numeric paired variables of more than two groups. Statistical data analysis was conducted by using the computer software SPSS version 13.0.

This ethics of this study has been approved by Research Ethics Comission Faculty of Medicine University of Indonesia. Informed consent was signed by the selected elderly subjects or by those who were responsible for the subjects. All of the subjects was treated fairly.

\section{RESULTS}

\section{Patients and clinical characteristics/laboratory results}

The number of elderly subjects included into the study was 107 people. Based on the predetermined exclusion criteria as well as on one drop-out at the end of the first week, it was stated that the number of subjects who completed the two-weeks study was 31 . No significant difference in clinical and laboratory characretistics was found in 5 subject groups before the interven tion commencement (table 1). No significant difference in nutrient intake in 5 subjects groups during two-weeks of the study.

No significant difference was found between the target of water intake and the mean water intake during the study in each group. In all the groups, volume of water intake, either before or after the intervention-the mean BUN-creatinine ratio did not exceed 20.

\section{Water intake and sodium status}

Prior to the intervention, no significant difference was found in the mean sodium concentrations in each group. The mean sodium concentrations were not found significantly different either among the five groups after one week 's intervention, so were the sodium concentrations in five groups after two weeks (table 2). Merely in group IV, significant difference was found between the mean sodium concentra- tions prior to intervention and the mean sodium concentration following the two weeks intervention $(\mathrm{p}=0.026)$.

As a group in the 31 subjects investigated, a significant difference was found in the mean sodium concentrations before intervention with the sodium concentrations after two week's intervention; however, no signifant difference was found between the sodium concentrations before intervention and the sodium concentration after one week's intervention (table 3). On the other side, a significant difference was found between the mean sodium discrepancy before and after the one week's intervention $(0.48 \pm 2.34 \mathrm{meq} / \mathrm{L})$ and the mean sodium discrepancy before and after the two week's intervention $(1.81 \pm 1.94 \mathrm{meq} / \mathrm{L}, \mathrm{p}=0.003)($ table 3$)$.

Table 1. Clinical and laboratory characteristics in five groups prior to intervention

\begin{tabular}{lcccccc}
\hline & Group 1 & Group 2 & Group 3 & Group 4 & Group 5 & p-value \\
\hline Age (in year) & $69.17 \pm 3.76$ & $70.67 \pm 5.75$ & $71.57 \pm 3.10$ & $70.14 \pm 9.72$ & $70.60 \pm 14.26$ & 0.270 \\
BW (Kg) & $48.00 \pm 10.33$ & $47.50 \pm 14.56$ & $49.28 \pm 7.27$ & $45.67 \pm 10.15$ & $40.60 \pm 5.08$ & 0.651 \\
BMI (Kg/m2) & $20.26 \pm 3.96$ & $20.51 \pm 4.84$ & $19.87 \pm 2.88$ & $21.61 \pm 8.05$ & $17.61 \pm 2.95$ & 0.814 \\
$\begin{array}{l}\text { Serum Natrium } \\
(\text { meq/L) }\end{array}$ & $142.33 \pm 2.07$ & $142.33 \pm 2.34$ & $143.14 \pm 1.67$ & $142.57 \pm 2.51$ & $143.20 \pm 2.28$ & 0.920 \\
\hline
\end{tabular}


Table 2. The mean of serum sodium before and after one and two weeks intervention

\begin{tabular}{lccccc}
\hline & Group 1 & Group 2 & Group 3 & Group 4 & Group 5 \\
\hline $\begin{array}{l}\text { Serum sodium pre- } \\
\text { intervension (meq/L) }\end{array}$ & $142.33 \pm 2.07$ & $142.33 \pm 2.34$ & $143.14 \pm 1.67$ & $\bullet 142.57 \pm 2.51$ & $143.20 \pm 2.28$ \\
$\begin{array}{l}\text { Serum sodium after } \\
\text { one week intervension (meq/L) }\end{array}$ & $141.83 \pm 1.17$ & $14183 \pm 2.48$ & $142.71 \pm 3.20$ & $141.86 \pm 2.79$ & $142.20 \pm 1.48$ \\
$\begin{array}{l}\text { Serum sodium after } \\
\text { one week intervension (meq/L) }\end{array}$ & $141.00 \pm 0.89$ & $140.67 \pm 1.63$ & $140.43 \pm 2.29$ & $\bullet 140.86 \pm 2.03$ & $141.80 \pm 3.11$ \\
\hline
\end{tabular}

* $p=0.026$

Tabel 3. The mean of serum sodium and the difference between the mean of serum sodium pre intervention with the mean of serum sodium after one or two weeks intervention in 31 elderly people

\begin{tabular}{|c|c|c|c|c|}
\hline & $\begin{array}{l}\text { The mean of } \\
\text { serum sodium } \\
\text { (meq/L) }\end{array}$ & $\mathrm{p}$-value & $\begin{array}{l}\text { The mean of } \\
\text { difference of serum } \\
\text { sodium (meq/L) }\end{array}$ & p-value \\
\hline $\begin{array}{l}\text { Pre intervention } \\
\text { with after one } \\
\text { week intervention }\end{array}$ & $\begin{array}{l}142.71 \pm 2.07 \\
\text { dan } \\
142.10 \pm 2.30\end{array}$ & 0.106 & $\# * 0.48 \pm 2.34$ & $* 0.003$ \\
\hline $\begin{array}{l}\text { Pre intervention } \\
\text { with after two } \\
\text { weeks intervention }\end{array}$ & $\begin{array}{l}142.71 \pm 2.07 \\
\quad \text { dan } \\
140.90 \pm 1.99\end{array}$ & 0.000 & $\wedge * 1.81 \pm 1.94$ & $\wedge 0.106$ \\
\hline $\begin{array}{l}\text { After one week intervention } \\
\text { with after two weeks } \\
\text { intervention }\end{array}$ & $\begin{array}{c}142.10 \pm 2.30 \\
\text { dan } \\
140.90 \pm 1.99\end{array}$ & 0.007 & $\#^{\wedge} 1.19 \pm 2.27$ & \# 0.354 \\
\hline
\end{tabular}

Three subject (10\%) were found to develop declined sodium concentrations $\geq 5 \mathrm{meq} / \mathrm{L}$ after the two week's intervention in group III, two subjects in group IV and one subject out of 31 subjects who followed this study.

\section{Water intake and ADH / NT-proBNP as well as urine osmolality}

In 31 elderly subjects, the mean plasma ADH level was $15.78 \pm 12.77 \mathrm{pg} / \mathrm{mL}$. No significant difference was found in the mean serum $\mathrm{ADH}$ levels before intervention among the groups of water intake. The median of plasma ADH levels in the group with sodium reduction $<5 \mathrm{meq} / \mathrm{L}$ was $10.4 \mathrm{pg} / \mathrm{mL}$ (IQR: $5.0-21.3$ ). The mean plasma ADH levels in the group with sodium reduction $\geq 5 \mathrm{meq} / \mathrm{L}$ was $27.43 \pm 8.66 \mathrm{pg} / \mathrm{mL}$. The plasma ADH levels in the group with sodium reduction $\geq 5 \mathrm{meq} / \mathrm{L}$ looked significantly higher $(p=0.041)$ compared with the ADH in the group with sodium reduction $<5 \mathrm{meq} / \mathrm{L}$ (table 4). 
Table 4. The differences in the group of sodium reduction before intervention and after two week intervention $<5$ meq/L with the group of sodium reduction before intervention and after two week intervention $\geq 5 \mathrm{meq} / \mathrm{L}$

\begin{tabular}{|c|c|c|}
\hline Group & $\begin{array}{l}\text { Sodium reduction } \\
<5 \mathrm{meq} / \mathrm{L}\end{array}$ & $\begin{array}{l}\text { Sodium reduction } \\
\quad \geq 5 \mathrm{meq} / \mathrm{L}\end{array}$ \\
\hline Age & $70.25 \pm 7.82$ & $72.33 \pm 4.04$ \\
\hline BMI (Kg/m2) & $19.65 \pm 3.73$ & $18.28 \pm 4.38$ \\
\hline Plasma ADH (pg/mL) & $\begin{array}{c}\text { median }=10,4 \\
(I Q R: 5.0-21.3)\end{array}$ & $27.43 \pm 8.66$ \\
\hline $\begin{array}{l}\text { Serum osmolality } \\
\left(\mathrm{mosmol} / \mathrm{kg} \mathrm{H}_{2} \mathrm{O}\right)\end{array}$ & $279.00 \pm 3.14$ & $279.67 \pm 6.35$ \\
\hline $\begin{array}{l}\text { Urine osmolality } \\
\left(\mathrm{mosmol} / \mathrm{Kg} \mathrm{H}_{2} \mathrm{O}\right)\end{array}$ & $537.43 \pm 179.88$ & $748.33 \pm 61.08$ \\
\hline Sodium in urine $(\mathrm{meq} / \mathrm{L})$ & ) $140.21 \pm 51.23$ & $166.00 \pm 51.21$ \\
\hline $\begin{array}{l}\text { NT-proBNP value } \\
\quad(\mathrm{pg} / \mathrm{mL})\end{array}$ & $\begin{array}{c}\text { Median }=259.7 \\
(\text { IQR: } 136.05-399.95)\end{array}$ & $339.93 \pm 119.05$ \\
\hline Cortisol $(\mu \mathrm{g} / \mathrm{dL})$ & $13.89 \pm 6.11$ & $14.07 \pm 2.34$ \\
\hline
\end{tabular}

There was a significant difference $(p=0.004)$ between the urine osmolality in the group with sodium reduction $\geq 5 \mathrm{meq} / \mathrm{L}$ and that of the group with sodium reduction $<5 \mathrm{meq} / \mathrm{L}$ (table 8 ). The median value of plasma NTproBNP in 31 subjects in this study was $259.7 \mathrm{pg} /$ $\mathrm{mL}$ (IQR: 136.05-399.95), and the means for male and female were $374 \pm 283$ and $275 \pm 171.6 \mathrm{pg} / \mathrm{mL}$ respectively. No significant difference was found in the mean plasma NT-proBNP levels among the groups of water intake before the intervention.

The mean of spot urine sodium of the 31 elderly subjects was $142.71 \pm 50.96 \mathrm{meq} / \mathrm{L}$ or $97 \%$ of the elderly subjects investigated had high sodium excretion in urine or more than $30 \mathrm{meq} / \mathrm{L}$. Significant correlation was not found between plasma NT-proBNP concentration before intervention and spot urine sodium before intervention.

\section{DISCUSSION}

The intervention duration that lasted two weeks was adequate to find out statistically significant differences in this study (table 3).

The mean of power of study in all of the groups was $98 \%$, it could be stated that after water intake intervention, sodium concentration should decline in healthy elderly population.

The potential factors that influenced the final outcomes of the study in each group were as same as proved by this study that there was no significant difference in ADH and NT-proBNP variables among the five groups. So was the case with other variables such as urinary concentrating ability, total body fluid, glomerular filtration rate, water clearance and aldosteron that were assumed to be not different in the five groups. Based on this fact, merely the factor of water intake volume that influenced the serum sodium concentrations which is in line with the objective of this study.

The results of this study could only be inferred to the elderly population that has fulfilled the criteria of healthy elderly such as aged more than 60, normovolemic, serum creatinine less than $2 \mathrm{mg} / \mathrm{dL}$ and not excluded from the study criteria and the setting and temperature should comply with the mean temperature of the study setting namely $28.7^{\circ} \mathrm{C}$, with the temperatures ranging from $26.7-30.8^{\circ} \mathrm{C}$.

In the normal physiology plasma ADH concen-tration just started to rise from the 0 point when the serum osmolality was $280 \mathrm{mosmol} / \mathrm{Kg} .{ }^{19}$ Whereas in this study the mean plasma $\mathrm{ADH}$ concentration was $15.78 \pm 12.77$ $\mathrm{pg} / \mathrm{mL}$ at the mean serum osmolality $279 \pm 3.4 \mathrm{mosmol} /$ $\mathrm{Kg}$. It could be deduced that the ADH increase was not triggered by the serum osmolality. In this study, the increase in plasma $\mathrm{ADH}$ was caused by the hyperplasia of paraventricular hypothalamic neurons. ${ }^{10,11}$ So was it before the intervention, considering that all of the elderly subjects included in this study were normovolemic so that the increase in ADH was not influenced by nonosmotic factors.

In the group with sodium reduction $\geq 5 \mathrm{meq} / \mathrm{L}$, in fact the $\mathrm{ADH}$ concentration was significantly higher than that of the group with sodium reduction $<5 \mathrm{meq} / \mathrm{L}$. This condition was reflected by the urine osmolality in the group with sodium reduction $\geq 5 \mathrm{meq} / \mathrm{L}$ that was significantly higher $(\mathrm{p}=0.004)$. Unraveling that there was a propensity for more water retention in three elderly subjects with $\mathrm{Na}$ reduction $\geq 5 \mathrm{meq} / \mathrm{L}$, so that the adminis $\neg$ tration of 1500 $\mathrm{mL}$ and $2000 \mathrm{~mL}$ of water intake led to the clinically significant drop of sodium concentration

It could be assumed that there was correlation between the high $\mathrm{ADH}$ and water intake to be able to induce hyponatremia in the elderly or not. The higher the plasma $\mathrm{ADH}$ concen $\neg$ tration, the more susceptible the elderly are to hyponatremia if given a high water intake. More interestingly, in group II with $1000 \mathrm{~mL}$ water intake, sodium reduction $\geq 5 \mathrm{meq} / \mathrm{L}$ did not occur despite the presence of two elderly subjects with ADH levels 46.1 $\mathrm{pg} / \mathrm{mL}$ and $52.8 \mathrm{pg} / \mathrm{mL}$ respectively, so that there was strong impression that it required more massive water intake than $1000 \mathrm{~mL}$ to induce hyponatremia.

What is actually the cut-off point to induce sodium reduction $\geq 5 \mathrm{meq} / \mathrm{L}$ in water intake initiating with 
1500-2500 mL? The mean ADH value in the group with sodium reduction $\geq 5 \mathrm{meq} / \mathrm{L}$ was $27.43 \pm 8.66 \mathrm{pg} /$ $\mathrm{mL}$ or the plasma $\mathrm{ADH}$ concentration ranged between 19-36 pg/mL. Analysis was done by employing Receiver Operator Curve (ROC),[20] initiating with group III, group-IV and group V. Based on this analysis, the cut-off point of ADH limit score was $19 \mathrm{pg} / \mathrm{mL}$. The total number of elderly subjects who joined the study in groups I,II,III,IV and V was 9 (31\%) people who had ADH concentration $\geq 19 \mathrm{pg} / \mathrm{mL}$ namely 2 subjects in the group of water intake volume based on Skipper method, 2 subjects in the group of $1000 \mathrm{~mL}$ water intake volume, 3 subjects in the group of 1500 $\mathrm{mL}$ water intake volume, one subject in the group of $2000 \mathrm{~mL}$ intake volume, and one subject in the group of $2500 \mathrm{~mL}$ water intake volume. This reveals that one third of the elderly group was potential to develop hyponatremia if given a water intake exceeding 1500 $\mathrm{mL}$ in twenty four hours. This condition is in line with what has been reported by some researchers that the frequency of hyponatremia at institutional elderly homes is quite high, ranging from $4,2-18 \%,{ }^{5-7}$ at which excessive water intake is the most frequent trigger. ${ }^{6}$ In our study, there were $3(60 \%)$ out of 5 elderly subjects with ADH concentration $\geq 19 \mathrm{pg} / \mathrm{mL}$ in the groups of $1500-2500 \mathrm{~mL}$ water intake that developed sodium concentration reduction $\geq 5 \mathrm{meq} / \mathrm{L}$. In the group of $1000 \mathrm{~mL}$, two subjects were found with $\mathrm{ADH} \geq 19 \mathrm{pg} /$ $\mathrm{mL}$; however, the serum sodium concentration did not decline to $\geq 5 \mathrm{meq} / \mathrm{L}$. It still requires further research to prove that the cut-off point of plasma ADH $19 \mathrm{pg} /$ $\mathrm{mL}$ is the threshold for the occurence of hyponatremia with the water intake $\geq 1500 \mathrm{~mL} / 24$ hour.

Based on the assumption and the fact of ADH influence, it is obvious that the safe water intake volume which did not cause sodium reduction $\geq 5 \mathrm{meq} / \mathrm{L}$ in this study was $1000 \mathrm{~mL} / 24$ hour. At the same time, it could be predicted that water intake up to $1000 \mathrm{~mL} / 24$ hour was an optimal water intake owing to the highest water intake volume that did not cause sodium reduction $\geq 5$ $\mathrm{meq} / \mathrm{L}$ and did not cause hypovolemia either.

The absence of significant difference in the mean body weight from group-I to group- $\mathrm{V}$, and the mean body weight of group-II was $47.50 \pm 14.55 \mathrm{Kg}$, so the mean water intake per $\mathrm{Kg}$ body weight which was safe and adequate for the elderly was $21.05 \mathrm{~mL} / \mathrm{Kg} \mathrm{BB}(1000 \mathrm{~mL}$ divided by $47.5 \mathrm{Kg}$ ) or rounded up to $21 \mathrm{~mL} / \mathrm{Kg} \mathrm{BW}$ with the minimal water intake of $1000 \mathrm{ml} \mathrm{mL} / 24$ hours.

Can reduced water intake lead to health problems? Dan Negoianu and Stanley Goldfarb in their editorials in J
Am Soc Nephrology in the year 2008 and also Valtin H. in his writing opposed this statement due to the absence of studies that met with the requirements of good studies to state the benefits of massive water intake. ${ }^{21,22}$

BNP has a moderate homolog with ANP. Like ANP, BNP levels also increase in the elderly and in those with renal function disorders whereas it is known that the elderly develop GFR decline. In the elderly, the cut-off point of NT-proBNP (amino-terminal probrain natri $\neg$ uretic-peptide) to determine if there is heart failure at GFR $\geq 60 \mathrm{~mL} /$ minute was $900 \mathrm{pg} / \mathrm{mL}$ in the elderdy aged above $50 .{ }^{23}$ In this investigation, the median of NT-proBNP at the same method as the report above[23] (Elecsys ProBNP, Roche Diagnostics, Indianapolis, Indiana) is $271.4 \mathrm{pg} / \mathrm{mL}(136-442 \mathrm{pg} /$ $\mathrm{mL})$. The cut off point of NT-proBNP or the reference values for males and females of less than 60 years of age were 100 and $164 \mathrm{pg} / \mathrm{mL}$ respectively. ${ }^{24}$ Most (72 percent) of elderly females and 75 percent of elderly males had higher plasma NT-proBNP levels than the reference value. The increase in plasma NT-proBNP level in this study was truly attributed to the late age because clinically signs and symptoms of heart failure were not found as well as the laboratory NT-proBNP value in this study was $<900 \mathrm{pg} / \mathrm{mL}$. The high plasma NT-proBNP level in this study is in line with what has been obtained by other researchers as well. ${ }^{25}$ It was well reliazed that the correlative analysis performed in this study, especially the correlation between NT-proBNP and natrium excretion in urine not to have fulfilled the adequate sample size. Nevertheless, with 31 subjects obtained, it has revealed no correlation. These findings have been supported by the three factors present in the elderly that influence sodium excretion in urine, among others, ANP, Aldosteron, ADH. Atrial Natriuretic Peptide or NT-proBNP and Aldosteron which will increase sodium excretion whereas ADH per se will increase sodium reabsorption at the collecting duct. ${ }^{26}$ In this study, ADH level was high, which would surely increase reabsorption at the collecting duct which at the same time caused spot urine sodium to have no correlation with NT-proBNP level.

\section{CONCLUSION}

As the conclusion of this study, water intake of 1000 $\mathrm{mL} / 24$ hours was an optimal water intake. In healthy elderly people, plasma ADH level has a role in the determination of water intake volume that does not cause hyponatremia. The analytical results revealed that ADH $19 \mathrm{pg} / \mathrm{mL}$ could be used as the cut-off point for the significant Natrium concentration reduction if the 
water intake was $1500 \mathrm{~mL} / 24$ hours. In healthy elderly people, plasma NT-proBNP level did not correlates with the spot urin sodium concentration.

As the recommendation, in healthy normovolemic elderly people, the recom mended water volume intake is 1000 $\mathrm{mL} / 24$ hours. The water intake up to $21 \mathrm{~mL} / \mathrm{Kg} \mathrm{BW}$ with the minimum of $1000 \mathrm{~mL} / 24$ hours is a safe water intake for healthy normovolemic elderly people. This study could be continued to prove the cut-off point value of $\mathrm{ADH}$ concentration is $19 \mathrm{pg} / \mathrm{mL}$ by comparing the upper and lower groups at the cut-off point toward the significant sodium concentration reduction after the intervention with the water intake volume of $1500 \mathrm{~mL} / 24$ hours.

\section{REFERENCES}

1. Luckey A, Parsa C. Fluid and electrolytes in the aged. Arch Surgery. 2003;138:1055-60.

2. Ayus JC, Armstrong D, Arieff AI. Hyponatremia with hypoxia: effects on brain adaptation, perfusion, and histology in rodents. Kidney Int 2006;69(8):1319-25.

3. Kokko J P. Symptomatic hyponatremia with hypoxia is a medical emergency. Kidney Int. 2006;69(8):1291-3.

4. Gankam Kengne F, Andres C, Sattar L, Melot C, Decaux G. Mild hyponatremia and risk of fracture in the ambulatory elderly. Qjm. 2008 Jul;101(7):583-8.

5. Chen L, Lin M, Hwang S, Chen T. Hyponatremia among the institutionalized elderly in 2 long-term care facilities in Taipei. J Chin Med Assoc. 2006;69(3):115-19.

6. Miller M, Morley J, Rubenstein L. Hyponatremia in a nursing home population $\mathrm{J}$ Am Geriatr Soc 1995;43(12):1410-3.

7. Tedjo J, Joseph E J. Hubungan kadar natrium serum dengan kejadian hipotensi ortostatik pada usia lanjut. Abstrak. Buku Program dan Abstrak, Pertemuan Ilmiah Tahunan (PIT) PERNEFRI, Makassar 2006; (November 23-26).

8. Anpalahan M. Chronic idiopathic hyponatremia in older people due to syndrome of inappropriate antidiuretic hormone secretion (SIADH) possibly related to aging. J Am Geriatr Soc 2001;49(6):788-92.

9. Siregar P. Frekuensi kejadian hiponatremia pada pasien usia lanjut yang rawat inap di Rumah Sakit Siloam, Lippo-Karawaci, Tangerang, selama tahun 2006. Belum dipublikasi 2007.

10. Johnson A, Crawford G, Kelly D, Nguyen T, AZ Gyory. Arginine vasopressin and osmolality in the elderly. . J Am Geriatr Soc. 1994;42(4):399-404.

11. Fliers E, Swaab D, Pool C, Verwer R. The vasopressin and oxytocin neurons in the human supraoptic and paraventricular nucleus; changes with aging and in senile dementia. . Brain Res. 1985;342(1):45-53.
12. Ying T, Serino R, Verbalis J. Downregulation of renal vasopressin V2 receptor and aquaporin-2 expression parallels age-associated defects in urine concentration. Am J Physiol Renal Physiol. 2004;287:797-805.

13. Iwazu Y, Honma S, Fujisawa G, Uki K, Yanaka I, Sato Y, et al. Hyponatremic seizure associated with acute respiratory infection. . Clin Experimental Neph 2007;11(3):230-4.

14. Radó J, Pató E, Iliás L, Iványi T, Rácz K, Laczi F. Repeated serious water intoxication in an aged patient. (Data on the relationship between the inappropriate antidiuretic hormone syndrome and the atrial natriuretic factor). Orv Hetil. 1995;136(4):189-93.

15. Chute J, Taylor E, Williams J, Kaye F, Venzon D, Johnson B. A Metabolic Study of Patients with Lung Cancer and Hyponatremia of Malignancy. Clin Cancer Res. 2006 February 1;12(3):888-96.

16. Chidester J, Spangler A. Fluid intake in the institutionalized elderly. J Am Diet Assoc. 1997;97:23-8.

17. Lindeman R, Romero L, Hwa C, Baumgartner R, Koehler K, Garry P. Do elderly persons need to be encouraged to drink moref fluids? J Gerontology. 2000;55A(7):M361-M5.

18. Halperin M, Goldstein M. Fluid, electrolyte, and acidbase physiology. a problem-based approach. Third ed: W.B.Saunders Company 1999.

19. Verbalis JG. Disorders of body water homeostasis. Best practice \& research. 2003 Dec;17(4):471-503.

20. Sastroasmoro S, Ismael.S, eds. Dasar-Dasar Metodologi Penelitian Klinis. 2nd ed. Jakarta: CV Sagung Seto 2006.

21. Negoianu D, Goldfarb S. Just Add Water. J Am Soc Nephrol. 2008;19:1041-48.

22. Valtin H. "Drink at least eight glasses of water a day." Really? Is there scientific evidence for "8 x 8"? Am J Physiol Regul Integr Comp Physiol 2002;283:R993-R1004.

23. Anwaruddin S, Lloyd-Jones DM, Baggish A, Chen A, Krauser D, Tung R, et al. Renal function, congestive heart failure, and amino-terminal pro-brain natriuretic peptide measurement: results from the ProBNP Investigation of Dyspnea in the Emergency Department (PRIDE) Study. J Am Coll Cardiol. 2006 Jan 3;47(1):91-7.

24. Galasko G I W, Lahiri A, Barnes S C, Collinson P, Senior $\mathrm{R}$. What is the normal range for $\mathrm{N}$-terminal pro-brain natriuretic peptide? How well does this normal range screen for cardiovascular disease? Eur Heart J. 2005;26:2269-76.

25. Costello-Boerrigter LC, Boerrigter G, Redfield MM, Rodeheffer RJ, Urban LH, Mahoney DW, et al. Aminoterminal pro-B-type natriuretic peptide and B-type natriuretic peptide in the general community: determinants and detection of left ventricular dysfunction. J Am Coll Cardiol. 2006 Jan 17;47(2):345-53.

26. Bankir L, Fernandes S, Bardoux P, Bouby N, Bichet DG. Vasopressin-V2 receptor stimulation reduces sodium excretion in healthy humans. J Am Soc Nephrol. 2005 Jul;16(7):1920-8. 
